Article

\title{
Relationship between fish length and otolith morphological characteristics of Sargocentron spiniferum (Forsskål, 1775) from the southern Red Sea
}

\author{
Yassein A. A. Osman ${ }^{1}$, Kélig Mahé ${ }^{2,}{ }^{*}$, Samia M. El-Mahdy ${ }^{1}$, Ashraf S. Mohammad ${ }^{1}$ and Sahar F. Mehanna $^{1}$ \\ 1 National Institute of Oceanography and Fisheries, Egypt; yasseinahmed66@yahoo.com \\ 2 Ifremer, Fisheries Laboratory, Sclerochronology Centre, Boulogne-Sur-Mer, France ; kelig.mahe@ifremer.fr \\ * Correspondence: kelig.mahe@ifremer.fr; Tel.: +0033 321995602
}

\begin{abstract}
Otolith morphology analysis is one of the main tools used for fish or fish stock identification. Moreover, otolith shape can also be used in fish dietary studies (stomach content) for the identification of prey fishes and their size according to the relationship between fish and otolith sizes. In the present study, the relationship between fish length and otolith morphological dimensions was investigated for the sabre squirrelfish, Sargocentron spiniferum (Forsskål, 1775) (family: Holocentridae). Samples of 185 fish were collected from the coast of the Red Sea, Egypt. To analyze the relationship between fish and otolith, otolith morphometric measurements (length, width, area, perimeter, weight, sulcus, and ostium) and shape factors (aspect ratio, compactness, form factor, rectangularity, roundness, ellipticity, squareness) describing outline shape were extracted using image analysis. Generalized linear models were applied for the relationship between body length and each otolith morphology feature. From the relationships between the total length of fish and fourteen morphology features, only otolith length, caudal length, and squareness were significantly correlated with fish size. Our results provide more information for the relationship between fish length and otolith morphometric features.
\end{abstract}

Keywords: Fish size; otolith shape; head side; Sargocentron spiniferum; Red Sea; Egypt.

\section{Introduction}

The sabre squirrelfish Sargocentron spiniferum (Forsskål, 1775) is a member of the family Holocentridae, which is mainly distributed in the Indo-Pacific from the Red Sea and East Africa to the Hawaiian Islands and Ducie Islands extending south to Australia. It is also distributed in New Caledonia, north to southern Japan and the Ogasawara Islands $[1,2]$. This species inhabits different reef areas between reef flats in lagoons and seaward reefs at a depth of $122 \mathrm{~m}$. This fish occurs under ledges during the day [3], and when smaller in size, this fish inhabits shallow, protected areas. It is a nocturnal fish that feeds on crabs, shrimp, and small fishes [4].

Many researchers have used the clear and distinct growth rings of sagittal otoliths to study the age and growth of fishes. Otoliths are calcified structures located at the right and left inner ears of fishes, which are useful in the study of fish biology, ecology, and fisheries science [5-7]. Otoliths are also used to estimate movement, varied habitat, population dynamics, and trophic level for fish species [7-15].

Otolith morphology is used to recognise fish species in taxonomic, phylogenetic, paleoichthyological and dietary studies [16-19]. Within species, otolith shape is also used to identify stocks. A recent study showed, however, that directional asymmetry between right and left otoliths within individuals could affect the results from the otolith shape analysis as tool to identify the stocks [20]. Consequently, the aim of the present work was to estimate the relationship between fish size and otolith outline features according to the 
location of the otolith, i.e., left versus right inner ear for S. spiniferum from the Egyptian waters of the Red Sea.

\section{Materials and Methods}

Fish species were randomly collected from the southern Red Sea at the Shalateen fishing port, which is located $520 \mathrm{~km}$ south of Hurghada (Figure 1), Egypt, between March 2018 and February 2019.

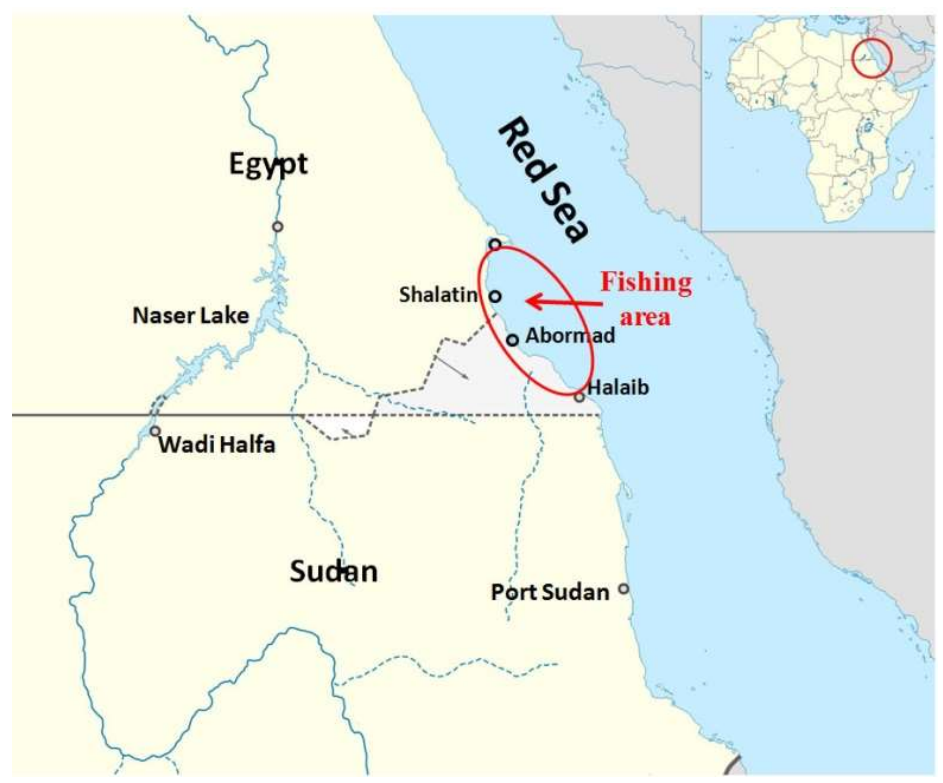

Figure 1. Egyptian Red Sea map showing the studied Shalateen area.

The fish were obtained from the commercial catch of the hook and line fishery at Shalateen fishing ground. In the laboratory, total fish length (TL) was measured to the nearest $0.1 \mathrm{~mm}$, then the sex was determined from macroscopic observation. The total length of the species ranged between 17.7 and $45.8 \mathrm{~cm}$. Sagittal otoliths ( 370 paired left and right otoliths) were extracted from the inner ear of $185 \mathrm{~S}$. spiniferum, cleaned and dried. Otolith weight (OW) for each head side was measured using a digital balance AS220 k/1 to the nearest $0.0001 \mathrm{~g}$. Otolith images were captured using a Euromex CMEX10 PRO camera with a stereomicroscope. The following otolith measurements: length (OL, $\mathrm{mm})$, width $(\mathrm{OH}, \mathrm{mm})$, area $(\mathrm{OA}, \mathrm{mm} 2)$, perimeter $(\mathrm{OP}, \mathrm{mm})$, sulcus length $(\mathrm{SU})$, ostium length (OS) were taken using image processing systems (Image J analysis software, [21]; detailed descriptions is in Figure 2). 


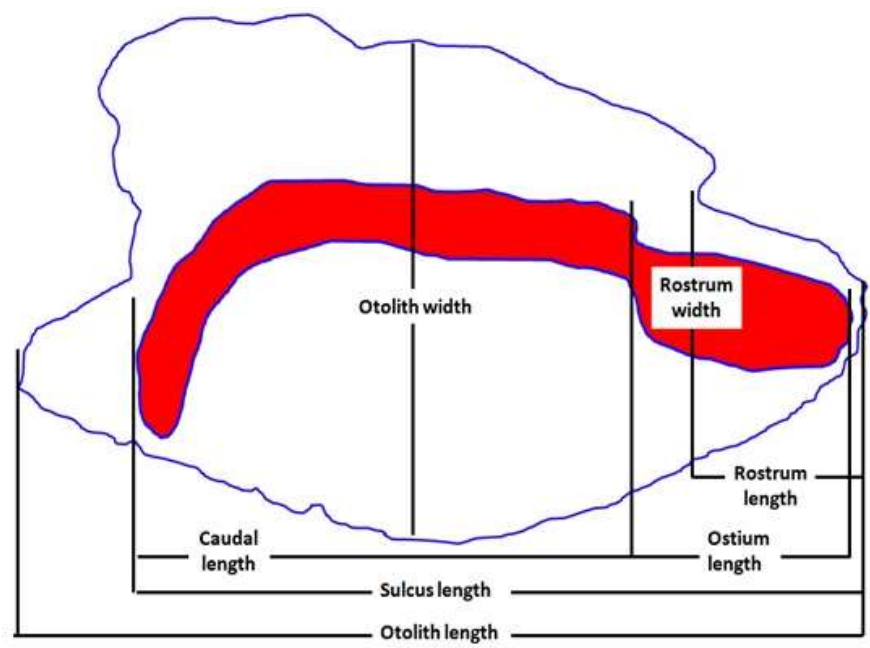

Figure 2. Diagram and scheme of the otolith of Sargocentron spiniferum illustrating various features of the otolith measurements.

From these size parameters, the following shape indices were calculated: form factor $(\mathrm{FF})$, aspect ratio $(\mathrm{AR})$, circularity $(\mathrm{CI})$ rectangularity $(\mathrm{RE})$, roundness $(\mathrm{RO})$, ellipticity (EL), compactness (C), and squareness (SQ) [21-28]. The formulae of these shape index factors (FF, C, AR, CI, RO, RE, EL, and SQ) are presented in Table 1. 
Table 1. Size dimension parameters and shape indices of otolith used to describe S. spiniferum otolith characteristics.

\begin{tabular}{|l|r|c|}
\hline Size parameters & \multicolumn{2}{|c|}{ Shape indices } \\
\hline Length : OL & Circularity : & $C I=\frac{O P}{O A^{2}}$ \\
\hline Width : OH & Ellipticity : & $E L=\frac{O L-O H}{O L+O H}$ \\
\hline Perimeter : OP & Roundness : & $R O=\frac{4 O A}{\pi O L^{2}}$ \\
\hline Area: OA & Aspect ratio: & $A R=\frac{O L}{O H}$ \\
\hline Weight: OW & Rectangularity : & $R E=\frac{O A}{O L . O H}$ \\
\hline Sulcus : OSL & Form-factor: & $F F=\frac{4 \pi O A}{O P^{2}}$ \\
\hline Ostium : OOs & Compactness : & $C O=\frac{O P^{2}}{O A}$ \\
\hline
\end{tabular}

Subsequently, the relationship of fish length with each otolith feature (size parameters or shape indices) was modelled according to the side (S):

$$
\log (\mathrm{TL}) \sim \text { Otolith feature + Side + Otolith feature:Side }
$$
[30].

Statistical analyses were performed in the R statistical environment [29] stats package

\section{Results}

A general pattern of $S$. spiniferum sagittae can be recognized in adult individuals: the otolith shape of $S$. spiniferum is ovate with sinuate margins, and is elongated, reflecting slower growth of the dorso-ventral axis compared to the antero-posterior axis. The dorsoventral axis has the highest growth, with with a much higher distance than that observed on antero-posterior axis with the rounded posterior area and the lobed anterior area. The sulcus acousticus is ostial with the heterosulcus and ostium formed by a short, funnel-like ostium that opens to the anterior margin, and closed, tubular cauda at least two times larger than the ostium (Figure 2). Descriptive statistics and paired t-test results for left and right otoliths of $S$. spiniferum are given in Table 2. 
Table 2. Summary of descriptive statistics and paired t-test results for left and right otoliths of S. spiniferum $(\mathrm{n}=185)$.

\begin{tabular}{|c|c|c|c|c|c|c|}
\hline \multicolumn{2}{|c|}{ Parameters (side) } & Minimum & Maximum & Mean & Std. Deviation & paired t test \\
\hline \multirow{2}{*}{ OL } & Left & 9.54 & 14.11 & 11.91 & 0.91 & \multirow{2}{*}{0.0880} \\
\hline & Right & 9.56 & 14.11 & 11.88 & 0.93 & \\
\hline \multirow{2}{*}{$\mathrm{OH}$} & Left & 5.75 & 9.97 & 7.55 & 0.86 & \multirow{2}{*}{0.3790} \\
\hline & Right & 6.04 & 9.97 & 7.57 & 0.83 & \\
\hline \multirow{2}{*}{ OW } & Left & 0.0365 & 0.1574 & 0.0648 & 0.0017 & \multirow{2}{*}{0.1931} \\
\hline & Right & 0.0255 & 0.1572 & 0.0643 & 0.0017 & \\
\hline \multirow{2}{*}{ OSL } & Left & 8.18 & 13.75 & 10.47 & 1.11 & \multirow{2}{*}{0.0000} \\
\hline & Right & 8.15 & 13.73 & 10.31 & 1.13 & \\
\hline \multirow{2}{*}{ OOs } & Left & 2.56 & 5.86 & 4.21 & 0.60 & \multirow{2}{*}{0.1120} \\
\hline & Right & 2.58 & 5.98 & 4.26 & 0.64 & \\
\hline \multirow{2}{*}{$\mathrm{OCu}$} & Left & 4.84 & 8.04 & 6.27 & 0.72 & \multirow{2}{*}{0.0000} \\
\hline & Right & 4.87 & 8.03 & 6.05 & 0.72 & \\
\hline \multirow{2}{*}{$\mathrm{OA}$} & Left & 43.44 & 91.29 & 66.89 & 0.729 & \multirow{2}{*}{0.18} \\
\hline & Right & 44.44 & 91.33 & 66.90 & 0.727 & \\
\hline \multirow{2}{*}{ OP } & Left & 25.01 & 40.01 & 32.278 & 0.194 & \multirow{2}{*}{0.17} \\
\hline & Right & 25.01 & 40.00 & 32.276 & 0.194 & \\
\hline \multirow{2}{*}{ AS } & Left & 0.500 & 0.730 & 0.633 & 0.040 & \multirow{2}{*}{0.135} \\
\hline & Right & 12.680 & 20.680 & 15.697 & 0.038 & \\
\hline \multirow{2}{*}{$\mathrm{CO}$} & Left & 0.150 & 0.250 & 0.201 & 1.389 & \multirow{2}{*}{0.073} \\
\hline & Right & 0.580 & 1.010 & 0.746 & 1.389 & \\
\hline \multirow{2}{*}{$\mathrm{FF}$} & Left & 0.490 & 0.740 & 0.601 & 0.019 & \multirow{2}{*}{0.319} \\
\hline & Right & 0.160 & 0.330 & 0.226 & 0.018 & \\
\hline \multirow{2}{*}{$\mathrm{RE}$} & Left & 12.680 & 20.680 & 15.697 & 0.072 & \multirow{2}{*}{0.791} \\
\hline & Right & 0.580 & 1.010 & 0.746 & 0.069 & \\
\hline \multirow{2}{*}{$\mathrm{RO}$} & Left & 0.530 & 0.740 & 0.637 & 0.058 & \multirow{2}{*}{0.072} \\
\hline & Right & 12.680 & 20.680 & 15.693 & 0.056 & \\
\hline \multirow{2}{*}{ EL } & Left & 0.150 & 0.250 & 0.201 & 0.031 & \multirow{2}{*}{0.113} \\
\hline & Right & 0.590 & 1.000 & 0.746 & 0.029 & \\
\hline & Left & 0.490 & 0.780 & 0.605 & 1.389 & \\
\hline $\mathrm{Cl}$ & Right & 0.150 & 0.310 & 0.223 & 1.389 & 0.073 \\
\hline & Left & 12.680 & 20.680 & 15.693 & 0.072 & \\
\hline SQ & Right & 0.590 & 1.000 & 0.746 & 0.069 & 0.791 \\
\hline
\end{tabular}

Otolith parameters: OL, length, OH- width, OW- weight, OSL- sulcus length, OOs- ostium length, OCu- caudal length, OA- area, OP- perimeter; lengths in $\mathrm{mm}$, weight in $\mathrm{g}$, area in $\mathrm{mm}^{2}$.

Analysis of the relationships between fish length and fourteen otolith shape descriptors using a generalized linear model showed that there is a significant relationship between eight otolith parameters (ostium length, caudal length, otolith area, otolith perimeter, compactness, form factor, circularity, and squareness) with the total length of fish. 
Only the relationship of body length with otolith length, caudal length and squareness $(\mathrm{P}<0.05)$ was significant for right and left otolith (Table 3$)$.

Table 3. Generalized linear models for the relationship between fish length and each otolith variable for S. spiniferum from the Red Sea with the significance (TL) and Side effect (observed from the interaction between Otolith feature and side in the GLM : Otolith feaTable 0 . The relationship between TL and each otolith descriptor was showed according to the significance of side effect, $\mathrm{OL}$, otolith length; $\mathrm{OH}$, otolith width; $\mathrm{SU}$, sulcus; OS, ostium; OA, otolith area; OP, otolith perimeter, $\mathrm{FF}$, form factor; $\mathrm{AR}$, aspect ratio; $\mathrm{C}$, compactness; $\mathrm{RE}$, rectangularity, $\mathrm{RO}$, roundness; $\mathrm{EL}$, ellipticity; C, circularity y; SQ, squareness.

\begin{tabular}{|c|c|c|c|c|}
\hline $\begin{array}{c}\text { Otolith } \\
\text { des criptor }\end{array}$ & TL & Side effect & Relations hip between TL and otolith descriptor & $\mathbf{R}^{2}$ \\
\hline \multirow{2}{*}{$\mathbf{O L}$} & \multirow{2}{*}{0.482} & \multirow{2}{*}{0.010} & Left side $\mathrm{TL}=0.719+0.065 \mathrm{OL}$ & $\mathrm{R}^{2}=0.665$ \\
\hline & & & Right side $\mathrm{TL}=0.636+0.072 \mathrm{OL}$ & $\mathrm{R}^{2}=0.852$ \\
\hline $\mathbf{O H}$ & 0.274 & 0.148 & $\mathrm{TL}=0.896+0.078 \mathrm{OH}$ & $\mathrm{R}^{2}=0.736$ \\
\hline $\begin{array}{l}\text { Sulcus } \\
\text { length }\end{array}$ & 0.078 & 0.336 & $\mathrm{TL}=0.904+0.057 \mathrm{SU}$ & $\mathrm{R}^{2}=0.777$ \\
\hline $\begin{array}{c}\text { Ostium } \\
\text { length }\end{array}$ & 0.008 & 0.621 & $\mathrm{TL}=1.116+0.087 \mathrm{OS}$ & $\mathrm{R}^{2}=0.586$ \\
\hline \multirow{2}{*}{$\begin{array}{l}\text { Caudal } \\
\text { length }\end{array}$} & \multirow{2}{*}{$<0.001$} & \multirow{2}{*}{$<0.001$} & Left side $\mathrm{TL}=1.117+0.069 \mathrm{CA}$ & $\mathrm{R}^{2}=0.384$ \\
\hline & & & Right side $\mathrm{TL}=1.047+0.007 \mathrm{CA}$ & $\mathrm{R}^{2}=0.806$ \\
\hline OA & $<0.001$ & 0.446 & $\mathrm{TL}=1.095+0.006 \mathrm{OA}$ & $\mathrm{R}^{2}=0.851$ \\
\hline OP & 0.007 & 0.986 & $\mathrm{TL}=0.689+0.025 \mathrm{OP}$ & $\mathrm{R}^{2}=0.813$ \\
\hline $\mathbf{A R}$ & 0.973 & 0.853 & $\mathrm{TL}=1.063+0.675 \mathrm{AR}$ & $\mathrm{R}^{2}=0.138$ \\
\hline C & 0.023 & 0.703 & $\mathrm{TL}=1.331+0.010 \mathrm{C}$ & $\mathrm{R}^{2}=0.037$ \\
\hline FF & 0.001 & 0.388 & $\mathrm{TL}=1.656-0.833 \mathrm{FF}$ & $\mathrm{R}^{2}=0.043$ \\
\hline $\mathbf{R E}$ & 0.301 & 0.642 & $\mathrm{TL}=1.807-0.427 \mathrm{RE}$ & $\mathrm{R}^{2}=0.166$ \\
\hline RO & 0.523 & 0.263 & $\mathrm{TL}=1.734-0.327 \mathrm{RO}$ & $\mathrm{R}^{2}=0.111$ \\
\hline EL & 0.574 & 0.091 & $\mathrm{TL}=1.686-0.872 \mathrm{EL}$ & $\mathrm{R}^{2}=0.132$ \\
\hline CI & $<0.001$ & 0.802 & $\mathrm{TL}=1.331+0.010 \mathrm{CI}$ & $\mathrm{R}^{2}=0.037$ \\
\hline \multirow{2}{*}{ SQ } & \multirow{2}{*}{$<0.001$} & \multirow{2}{*}{$<0.001$} & Left side $\mathrm{TL}=1.734-0.328 \mathrm{SQ}$ & $\mathrm{R}^{2}=0.111$ \\
\hline & & & Right side $\mathrm{TL}=1.785-0.396 \mathrm{SQ}$ & $\mathrm{R}^{2}=0.138$ \\
\hline
\end{tabular}

The correlation between fish total length and otolith morphology showed that with an increase in the total length, the following factors of otolith morphology also increase: length, width, sulcus length, ostium length, caudal length, area, and perimeter (Figure 3). These relationships between body length and otolith measurements (left and 
right) were best fitted as linear regression. The relationship between body length and the aspect ratio was, however, close to 1 , confirming that the otolith of S. spiniferum was oval. There is a positive relationship between total length and the aspect ratio, and the compactness and circularity values. The form factor, rectangularity, roundness, ellipticity, and squareness values decreased as the TL decreased.
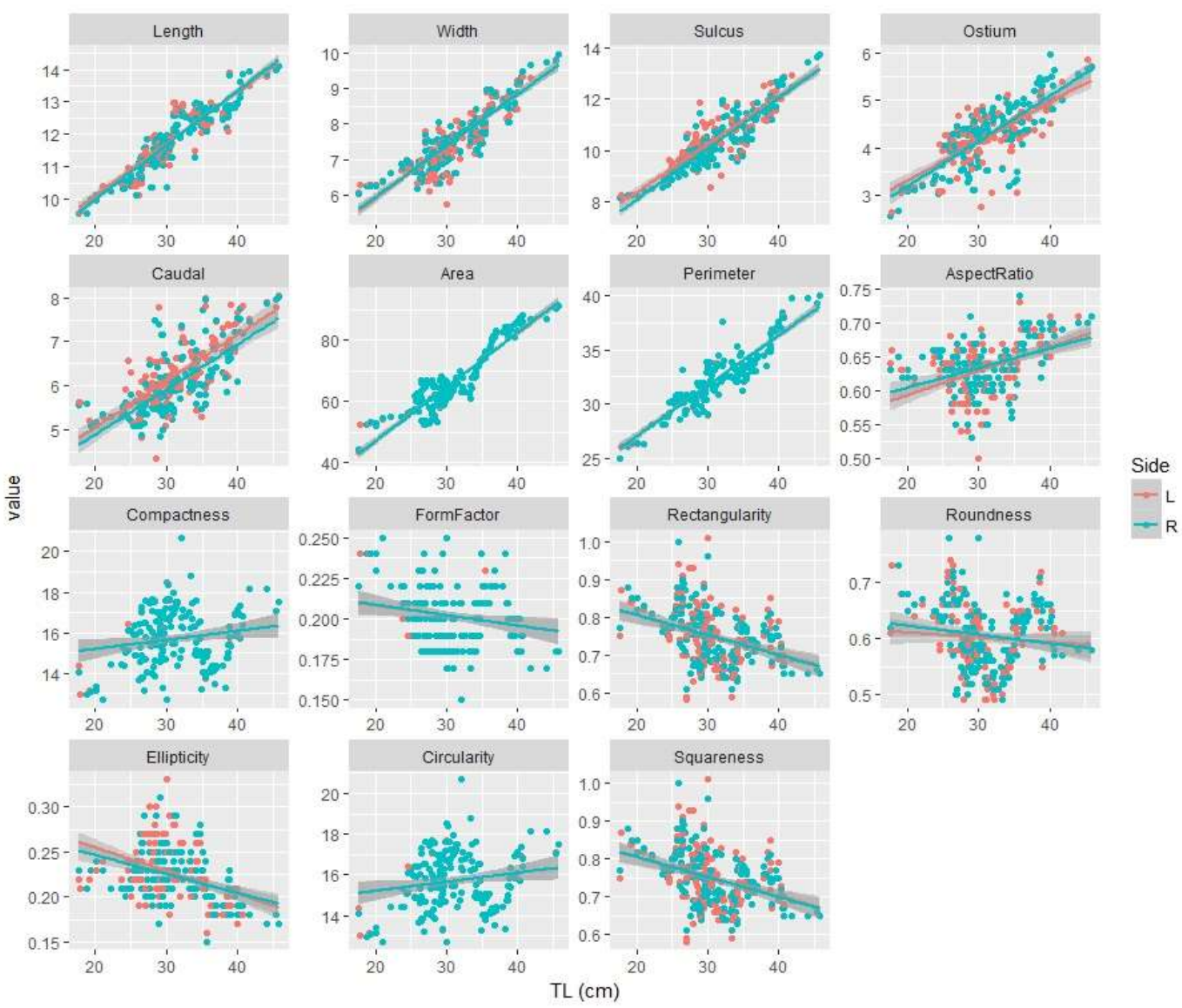

Figure 3. Relationships of body length with the otolith morphological structures (red points = left otolith, and green points = right otolith) according to the side of $S$. spiniferum captured from Shalateen, Red Sea, Egypt.

\section{Discussion}

The sabre squirrelfish Sargocentron spiniferum (Forsskål, 1775) contributes to important fisheries, especially the small artisanal fisheries at Shalateen fishing ground, Red Sea, Egypt. Basic data on the biology and dynamics of the species are essential for successful stock assessment and consequently in fisheries management. The observed fish length and shape of the otolith in this study should encourage more research to verify the essential role of otolith morphometric measurements in fish stock identification. The strong correlation between the somatic length and otolith size suggests that somatic growth has a significant influence on the otolith growth $[9,31]$. The results of this study were not similar to those previously obtained for the redcoat S. rubrum [26], where the present study shows greater otolith length, weight and height than S. rubrum. Previous studies have focused mainly on the relationship between otolith measurements and fish length [6, 3236]. In our study, the results of generalized linear models showed that the relationship among these parameters is variable as the otolith length can be affected by the choice of the otolith (significant asymmetry between right and left otoliths). For this species, if the 
relationship between fish size and otolith size is used, it is necessary to identify the used side to avoid introducing a bias in the results. Moreover, otolith asymmetry could be considered as a sensitive indicator of fish health that directly affects the fish performance because otoliths are essential to balance and hearing [37-38]. Based on the present data, the relationships between $\mathrm{TL}$ and $\mathrm{AR}, \mathrm{CO}$, and $\mathrm{CI}$ were determined as linear, while the relationships among TL and FF, RE, RO, EL, and SQ were determined as nonlinear. The shape of otolith from different geographical areas is, however, influenced by both environmental parameters (e.g salinity, temperature) and biotic parameters, for example prey availability, and depends on individual genotype [9,39-41]. Consequently, an interaction of environmental and genetic fluctuation generates the morphological variance in otolith shape that may allow the differentiation of stock units. However, the factors that affects the shapes are not fully understood and have not yet been investigated deeply [42]. A recent and on-going work showed that the ontogenetic trajectory of otolith shape could be impacted by the environmental disturbance during the early life stage [43]. The relationships between fish size and otolith shape indices demonstrate the high variability in fish length and morphometric parameters, indicating that the otolith of S. spiniferum is rectangular to oval. The results of this study on the fish size and otolith morphometric parameters are useful for further research on verifying the role of otoliths in identification, discrimination and taxonomic classification of fish. The results concur with previous studies showing that otoliths can be widely used for the discrimination and variation of fish species because of their form, diet, weight, and growth [44,45]. Finally, the estimation of the generalized linear models in the present work may be good tool to study the relationship between fish and otolith morphometric features, which are used for fish population dynamics, stomach contents analyses of piscivorous predators, paleontological composition, and yield estimates.

Author Contributions: Conceptualization, methodology Y.A. A. O., S. M. E. M., A. S. M. and S. F. M.; formal analysis, Y.A. A. O. and K. M.; writing-original draft preparation, Y.A. A. O.; writingreview and editing, K.M.

Acknowledgments: We would especially thank K. M. MacKenzie for this valuable help in editing this manuscript.

Conflicts of Interest: The authors declare no conflict of interest.

\section{References}

1. Randall, J.; Greenfield, D. Holocentridae: squirrelfishes (soldierfishes). FAO species identification guide for fishery purposes: the living marine resources of the Western Central Pacific: Bony fishes 1999, 2225-2256.

2. Randall, J.E. Zoogeography of shore fishes of the Indo-Pacific region. Zoological Studies 1998, 37, 227-268.

3. Lieske, E.; Myers, R. Coral reef fishesCaribbean, Indian Ocean and Pacific Ocean including the red sea 1994

4. Kuiter, R.H.; Tonozuka, T. Pictorial guide to Indonesian reef fishes: Zoonetics; 2001

5. Tuset, V.; Lozano, I.; González, J.; Pertusa, J.; GarcíaDíaz, M. Shape indices to identify regional differences in otolith morphology of comber, Serranus cabrilla (L., 1758). Journal of Applied Ichthyology 2003, 19, 88-93.

6. Mehanna, S.; Jawad, L.; Ahmed, Y.; Abu ElRegal, M.; Dawood, D. Relationships between fish size and otolith measurements for Chlorurus sordidus (Forsskål, 1775) and Hipposcarus harid (Forsskål, 1775) from the Red Sea coast of Egypt. Journal of Applied Ichthyology 2016, 32, 356-358.

7. Tuset, V.M.; Lombarte, A.; Gonzalez, J.; Pertusa, J.; Lorente, M. Comparative morphology of the sagittal otolith in Serranus spp. Journal of Fish Biology 2003, 63, 1491-1504.

8. Campana, S.E.; Casselman, J.M. Stock discrimination using otolith shape analysis. Canadian Journal of Fisheries and Aquatic Sciences 1993, 50, 1062-1083.

9. Cardinale, M.; Doering-Arjes, P.; Kastowsky, M.; Mosegaard, H. Effects of sex, stock, and environment on the shape of knownage Atlantic cod (Gadus morhua) otoliths. Canadian Journal of Fisheries and Aquatic Sciences 2004, 61, 158-167.

10. Rooker, J.R.; Secor, D.H.; DeMetrio, G.; Kaufman, A.J.; Ríos, A.B.; Tiina, V. Evidence of trans-Atlantic movement and natal homing of bluefin tuna from stable isotopes in otoliths. Marine Ecology-Progress Series, 2008, 368, 231-239.

11. Yilmaz, S.; Yazicioglu, O.; Saygin, S.A.; Polat, N. Relationships of Otolith Dimensions with Body Length of European Perch, Perca fluviatilis L., 1758 From Lake Ladik, Turkey. Pakistan J Zool. 2014, 46, 1231-1238. 
12. Zischke, M.T.; Litherland, L.; Tilyard, B.R.; Stratford, N.J.; Jones, E.L.; Wang, Y.-G. Otolith morphology of four mackerel species (Scomberomorus spp.) in Australia: Species differentiation and prediction for fisheries monitoring and assessment. Fisheries Research. 2016, 176, 39-47.

13. Zorica, B.; Sinovi, G.; Kel, V. Preliminary data on the study of otolith morphology of five pelagic fish species from the Adriatic Sea (Croatia). Acta Adriatica 2010, 51-89.

14. Sadighzadeh, Z.; Tuset, V.M.; Valinassab, T.; Dadpour, M.R.; Lombarte, A. Comparison of different otolith shape descriptors and morphometrics for the identification of closely related species of Lutjanus spp. from the Persian Gulf. Marine Biology Research, 2012, 8, 802-814.

15. Morat, F.; Letourneur, Y.; Nérini, D.; Banaru, D.; Batjakas, I.E. Discrimination of red mullet populations (Teleostean, Mullidae) along multi-spatial and ontogenetic scales within the Mediterranean basin on the basis of otolith shape analysis. Aquatic Living Resources 2012, 25, 27-39.

16. Tuset, V.M.; Rosin, P.L.; Lombarte, A. Sagittal otolith shape used in the identification of fishes of the genus Serranus, Fish. Res., 2006, 81, 316-325.

17. Škeljo, F.; Ferri, J. The use of otolith shape and morphometry for identification and size-estimation of five wrasse species in predator-prey studies. Journal of Applied Ichthyology, 2011, 28, 524-530.

18. Jawad, L. A.; Hoedemakers, K.; Ibáñez, A.; Ahmed, Y.; Abu ElRegal, M.; Mehanna, S. Morphology study of the otoliths of the parrotfish, Chlorurus sordidus (Forsskål, 1775) and Hipposcarus harid (Forsskål, 1775) from the Red Sea coast of Egypt (Family: Scaridae). Journal of the Marine Biological Association of the United Kingdom 2017, 1-10.

19. Disspain, Morgan C.F.; Ulm, Sean.; Gillanders, Bronwyn M. Otoliths in archaeology: methods, applications and future prospects. Journal of Archaeological Science: Reports 2016, 6, 623-632.

20. Mahé, K.; Ider, D.; Massaro, A.; Hamed, O.; Jurado-Ruzafa, A.; Gonçalves, P.; Anastasopoulou, A.; Jadaud, A.; Mytilineou, C.; Elleboode, R. Directional bilateral asymmetry in otolith morphology may affect fish stock discrimination based on otolith shape analysis. ICES Journal of Marine Science 2018, 76, 232-243.

21. Rohlf, F. tpsDig 2.10. Stony Brook, NY: Department of Ecology and Evolution, State University of New York; 2006

22. Russ, J. Computer-Assisted Microscopy.-The Measurement and Analysis of Image, 71-79. New York: Plenum Press Corp; 1990

23. Pavlov, D.; Emelyanova, N.; Ha, V.T.; Thuan, L.T.B. Otolith morphology, age, and growth of freckled goatfish Upeneus tragula (Mullidae) in the coastal zone of Vietnam. Journal of Ichthyology, 2015, 55, 363-372.

24. Zischke, M.T.; Litherland, L.; Tilyard, B.R.; Stratford, N.J.; Jones, E.L.; Wang, Y.-G. Otolith morphology of four mackerel species (Scomberomorus spp.) in Australia: Species differentiation and prediction for fisheries monitoring and assessment. Fisheries Research, 2016, 176, 39-47.

25. Mahe, K.; Evano, H.; Mille, T.; Muths, D.; Bourjea, J. Otolith shape as a valuable tool to evaluate the stock structure of swordfish Xiphias gladius in the Indian Ocean. African journal of marine science 2016, 38, 457-464.

26. Kabakli, F.; Ergüden, D. Relationships between Fish Length and Otolith Dimensions of Redcoat, Sargocentron rubrum (Forsskal, 1775) in the Southeastern Mediterranean Sea, Turkey. Turkish Journal of maritime and marine and marine sciences 2018, 4(2), 156162.

27. Mahé, K.; Bellamy, E.; Delpech, J.P.; Lazard, C.; Salaun, M.; Vérin, Y.; Coppin, F.; Travers-Trolet, M. Evidence of a relationship between weight and total length of marine fish in the North-eastern Atlantic Ocean: physiological, spatial and temporal variations. Journal of the Marine Biological Association of the United Kingdom 2018, 98, 617-625.

28. Osman, A.; Farrag, M.; Mehanna, S.; Osman, Y. Use of otolithic morphometrics and ultrastructure for comparing between three goatfish species (family: Mullidae) from the northern Red Sea, Hurghada, Egypt. Iranian Journal of Fisheries Sciences 2020, 19, 814-832.

29. Fox, J.; Weisberg, S. Multivariate linear models in R. An R Companion to Applied Regression Los Angeles: Thousand Oaks; 2011

30. R Development Core Team. R. A language and environment for statistical computing. R Foundation for Statistical Computing. Vienna, Austria. 2016

31. Jockusch, E.L. Geographic variation and phenotypic plasticity of number of trunk vertebrae in slender salamanders, Batrachoseps (Caudata: Plethodontidae). Evolution 1997, 51, 1966-1982.

32. Harvey, J.T.; Loughlin, T.R.; Perez, M.A.; Oxman, D.S. Relationship between fish size and otolith length for 63 species of fishes from the eastern North Pacific Ocean. 2000 Seattle, WA, NOAA/National Marine Fisheries Service, (NOAA Technical Report NMFS, 150)

33. Fossen, I.; Albert, O.T.; Nilssen, E.M. Improving the precision of ageing assessments for long rough dab by using digitised pictures and otolith measurements. Fisheries Research, 2003, 60, 53-64.

34. Lychakov, D.; Rebane, Y.; Lombarte, A.; Fuiman, L.; Takabayashi, A. Fish otolith asymmetry: morphometry and modeling. Hearing research 2006, 219, 1-11.

35. Morat, F.; Banaru, D.; Mérigot, B.; Batjakas, I.E.; Betoulle, S.; Vignon, M.; Lecomte-Finiger, R.; Letourneur, Y. Relationships between fish length and otolith length for nine teleost fish species from the Mediterranean basin, Kerguelen Islands, and Pacific Ocean. Cybium 2008, 32, 265-269.

36. Pavlov, D. Differentiation of three species of the genus Upeneus (Mullidae) based on otolith shape analysis. Journal of Ichthyology 2016, 56, 37-51. 
37. Hilbig, R.; Knie, M.; Shcherbakov, D.; Anken, R. H. Analysis of Behaviour and Habituation of Fish Exposed to Diminished Gravity in Correlation to Inner Ear Stone Formation - A Sounding Rocket Experiment (TEXUS 45). Proceedings of the 20th ESA Symposium on European Rocket and Balloon Programmes and Related Research, 22-26 May 2011, Hyere, France.

38. Lemberget, T.; Mccormick, M. I. Replenishment success linked to fluctuating asymmetry in larval fish. Oecologia 2009, 159, 8393.

39. Gagliano, M.; McCormick, M.I. Feeding history influences otolith shape in tropical fish. Marine Ecology Progress Series 2004, 278, 291-296.

40. Swan, C.M.; Palmer, M.A. Preferential feeding by an aquatic consumer mediates non-additive decomposition of speciose leaf litter. Oecologia, 2006, 149, 107-114.

41. Vignon, M.; Morat, F. Environmental and genetic determinant of otolith shape revealed by a non-indigenous tropical fish. Marine Ecology Progress Series 2010, 411, 231-241.

42. Burke, N.; Brophy, D.; King, P.A. Otolith shape analysis: its application for discriminating between stocks of Irish Sea and Celtic Sea herring (Clupea harengus) in the Irish Sea. ICES Journal of Marine Science 2008, 65, 1670-1675.

43. Vignon, M. Short-term stress for long-lasting otolith morphology-brief embryological stress disturbance can reorient otolith ontogenetic trajectory. Canadian Journal of Fisheries and Aquatic Sciences 2018, 75, 1713-1722.

44. Tuset, V.M.; Lombarte, A.; Assis, C.A. Otolith atlas for the western Mediterranean, north and central eastern Atlantic. Scientia Marina 2008, 72, 7-198.

45. Bacha, M.; Moali, A.; Benmansour, N.-E.; Brylinski, J.-M.; Mahe, K.; Amara, R. Relationships between age, growth, diet and environmental parameters for anchovy (Engraulis encrasicolus L.) in the Bay of Bénisaf (SW Mediterranean, west Algerian coast). Cybium 2010, 34, 47-57. 